\title{
Article \\ Smoke Particle, Polycyclic Aromatic Hydrocarbons and Total Benzo[a]pyrene Toxic Equivalence Emitted by Palm Oil Sewage Sludge Bio-Char Combustion
}

\author{
Wachara Kalasee and Panya Dangwilailux *
}

Citation: Kalasee, W.; Dangwilailux,

P. Smoke Particle, Polycyclic

Aromatic Hydrocarbons and Total Benzo[a]pyrene Toxic Equivalence Emitted by Palm Oil Sewage Sludge Bio-Char Combustion. Appl. Sci. 2021, 11, 8339. https://doi.org/10.3390/ app11188339

Academic Editor: Carmen Zaharia

Received: 24 August 2021

Accepted: 6 September 2021

Published: 8 September 2021

Publisher's Note: MDPI stays neutral with regard to jurisdictional claims in published maps and institutional affiliations.
King Mongkut's Institute of Technology Ladkrabang, Prince of Chumphon Campus, Chumphon 86160, Thailand; wachara.ka@kmitl.ac.th

* Correspondence: panya.da@kmitl.ac.th

\begin{abstract}
The size distribution, total particle mass concentration (TPMC), polycyclic aromatic hydrocarbons (PAHs) value, and total Benzo[a]pyrene Toxic Equivalence (BaPTE) concentration of smoke particles from palm oil sewage sludge (POSS) bio-char combustion were studied. In this experiment, temperature data of the POSS bio-char combustion were recorded in two parts: particle temperature (Tp) by using a two-color pyrometer and temperature at 300, 500 and $800 \mathrm{~mm}$, respectively, above the fire base by using K-type thermocouples. The POSS bio-char moisture content, clean air speed values, and burning period affected the change of temperature above the fire base. The mass median aerodynamic diameter (MMAD) values of the POSS bio-char combustion were found to be 0.44 to 1.05 micron at various moisture contents and burning periods. The MMAD, TPMC, and PAHs values increased with increasing moisture content and decreased the POSS bio-char combustion period. For the total BaPTE values, the results showed that the decrease in moisture content of the POSS bio-char samples had a prime influence in decreasing the total BaPTE values. Meanwhile, with decreases in the clean air speed values, the total BaPTE values were increased. Comparing the total BaPTE data between the experimental results and predicted values, the first-degree model had a better fit in predicting than the zero-degree model; this result was confirmed by the higher mean of the coefficient of determination.
\end{abstract}

Keywords: POSS bio-char combustion; benzo[a]pyrene toxic equivalence; size distribution; prediction; PAHs

\section{Introduction}

Oil palm (Elaeis guineensis) is a well-known economic crop throughout the world [1]. In Thailand, oil palm generates an income similar to rice (Oryza sativa L.) and para rubber (Hevea brasiliensis) [2,3]. In 2018, the oil palm plantation area in Thailand was 0.94 million hectares, producing 15.5 million tons of palm oil. [4]. Recently, Thailand has become the world's third-largest producer and exporter of palm oil [4,5], primarily due to the increased usage of biodiesel internationally. This usage of biodiesel is driven by increasing petroleum price, and so crude palm oil (CPO) consumption has also increased [5-7].

The yield of CPO is about $17-20 \%$ of the fresh fruit bunch (FFB) [8]. In the CPO process, decanter cake or palm oil sewage sludge (POSS) is the semi-solid residue obtained after the dehydration of palm oil mill effluent (POME). During the oil extraction and cleaning process, the report of Chavalparit et al. [9] showed that an average value of $42 \mathrm{~kg}$ POSS per ton of FFB is generated by palm oil mills. Meanwhile, the report of the Office of Agricultural Economics [4] showed that palm oil production is about 15.5 million tons per year, and the production of POSS is forecasted to be 651,000 tons.

Reviews of Renewable Energy Source (RES) produced from the sewage sludge (SS) of industry wastewater treatment plants were discussed as follows. The study of Begum et al. [10] shows that SS should be considered a good RES due to the fact that energy 
generation from SS produces substantially lower air pollution emissions than energy produced from fossil fuel combustion. For POSS, the reports of Chavalparit et al. [9] and Paepatung et al. [11] show that POSS comprises high mineral, fat, and protein content. Thus, it is used in biogas production, soil cover materials, and fertilizer in oil palm plantation areas. The report of Photong and Wongthanate [12] shows that POSS has a good potential as a future energy source, because it has recently been used as renewable energy source for power generation and as furnace combustion material.

Smoke particles and polycyclic aromatic hydrocarbons (PAHs) are produced by the incomplete combustion of carbonaceous materials [13-16]. The physicochemical properties of smoke particles and PAH profiles from the combustion of various kinds of raw materials such as rubber wood [17-21], bamboo wood [22-24], and rice husk [25-27] were investigated. The results of the smoke particles and PAHs emissions were found to depend on the moisture content, fuel type, amount of excess air, and the biomass blending ratio $[17,18,28]$. However, there is a lack of understanding of important parameters that significantly influence the emission of smoke particles and are associated with PAHs from POSS combustion under different combustion conditions. Until now, there has been no research on the smoke particle parameters, PAHs, and the prediction of the potential human health risks by analyzing the total Benzo[a]pyrene Toxic Equivalence (BaPTE) values from POSS bio-char combustion.

Thus, this article focuses on the characteristics of smoke particles, PAHs, and the prediction of the total BaPTE values in the emissions from POSS bio-char combustion. The characteristics include size distribution, concentration, and PAH components. The effects of the POSS bio-char burning period, clean air speeds, and moisture content on the smoke particles and PAHs emission are elaborated upon. This study should be useful for helping to solve energy decreases, environmental problems, and potential future human health risks.

\section{Materials and Methods}

\subsection{Materials}

The raw materials (POSS) used in this study were produced at a palm oil industry wastewater treatment plant in Chumphon Province, Thailand. The original material was sun dried for approximately five days before undergoing pyrolysis at $500{ }^{\circ} \mathrm{C}$ for two hours. Then, the POSS bio-char was sprayed with water, collected, and stored in a refrigerator until the moisture content was $60 \%$ on a dry basis (d.b.). POSS bio-char samples, which had a moisture content of $15 \%, 30 \%$ and $45 \%$ d.b., were prepared by using an electric air oven (Mammert 400, Swabach, Germany) at $50{ }^{\circ} \mathrm{C}$, while the completely dried POSS bio-char samples were dried at $103^{\circ} \mathrm{C}$ in an electric air oven for $24 \mathrm{~h}$ until a constant weight was reached $[17,29]$. A photograph of the POSS bio-char is shown in Figure 1.

\subsection{Sampling Methods}

In each experimental condition, $10.0 \mathrm{~kg}$ of POSS bio-char sample was burned in the combustion system. During combustion, the air speed conditions were set at $0.1,0.2$, and $0.3 \mathrm{~m} / \mathrm{s}$ by using a centrifugal blower (Nitco, model RB60-520, Hessdorf, Germany). Dependent on the bio-char sample's initial average moisture condition, they were divided into four groups of $15 \%, 30 \%, 45 \%$, and $60 \%$ d.b. There were five repetitions for every sample experimental group. Thus, 420 bits of data (12 run $\times 7$ time $\times 5$ repeat) were used for the construction of these models. The source smoke particles from the oven were sampled by three groups of apparatus to determine the size distribution, total concentration, and PAHs values. (Figure 2).

\subsection{Temperature Measurement}

In this study, the temperature measurement was divided into two parts: particle temperature $(T p)$ and the temperature at 300,500 and $800 \mathrm{~mm}$, respectively, above the fire base. For the particle temperature, it was measured and considered at $100 \mathrm{~mm}$ above the 
fire base by using a two-color pyrometer (Advanced Energy, Impac 8 pro Series, New York, NY, USA). The principle of this apparatus is comparing the radiation source intensities emitted at 550 and $700 \mathrm{~nm}$ wavelength ranges. Meanwhile, the temperature data at 300, 500 and $800 \mathrm{~mm}$, respectively, above the fire base were measured by using a data logger (Data-Taker, DT500, Melbourne, Australia) and K-type thermocouples. The temperature data were recorded and considered after the POSS bio-char was burned for 5, 15, 25, 35, 45,55 , and $65 \mathrm{~min}$, respectively. The experimental data logger continuously recorded the temperatures at $1 \mathrm{~min}$ intervals.

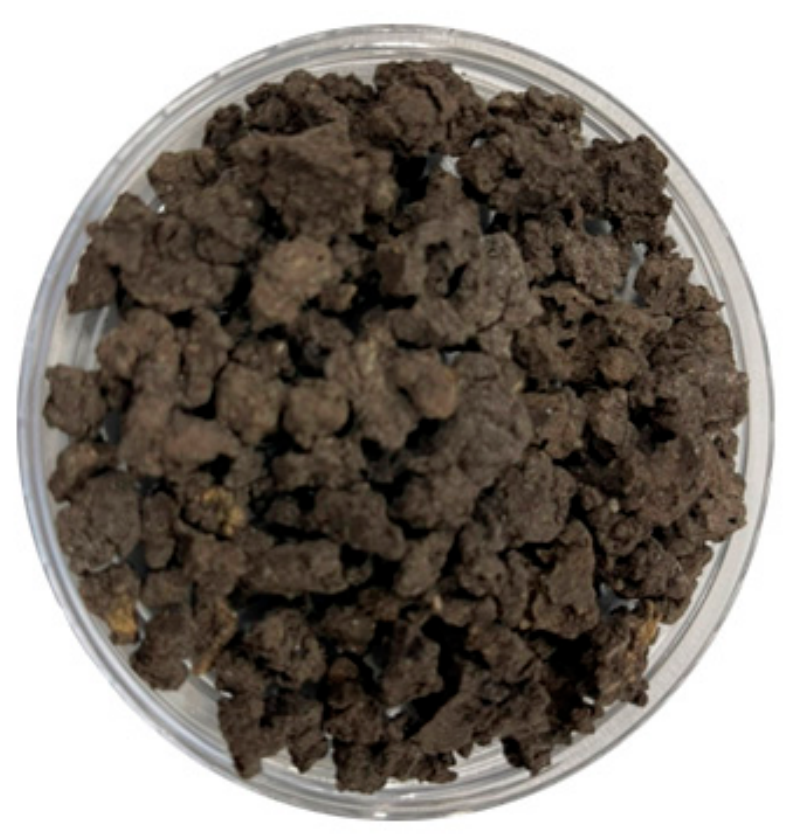

Figure 1. A photograph of palm oil sewage sludge bio-char.

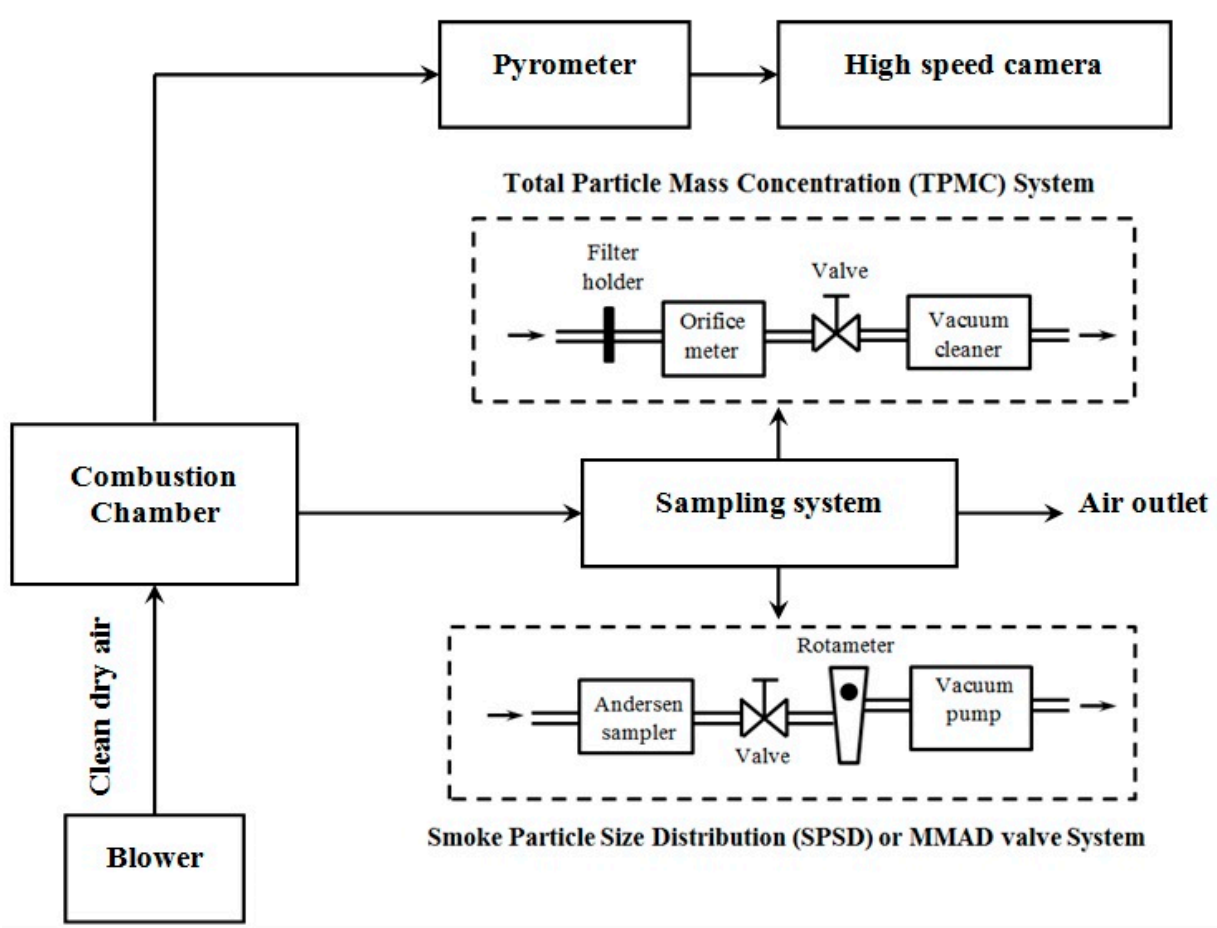

Figure 2. Schematic of the experimental set-up. 


\subsection{Smoke Particles Size Distribution}

The size distribution and the geometric standard deviation (GSD) value of the smoke particles from the bio-char combustion were recorded and calculated by collecting particles by using an 8-stage Andersen air sampler (Dylec, AN200, Tokyo, Japan). This sampler had cut-sizes of $0.43,0.65,1.1,2.1,3.3,4.7,7.0$, and 11.0 micron. Meanwhile, the smoke particles which had a dimension smaller than 0.43 micron were collected at the bottom stage by a backup filter. The experimental air flow rate was set at $28.3 \mathrm{lpm}$ by using a flow controller system (Figure 2). For each stage of the air sampler, a quartz-type fibrous filter (ADVENTEC, QR-100, Tokyo, Japan) with a diameter of $80 \mathrm{~mm}$ was placed on the glass plate and used to collect the smoke particles. The particle size distribution was measured after the bio-char had burned for 5, 15, 25, 35, 45, and $55 \mathrm{~min}$, respectively, and each experiment was taken over $5 \mathrm{~min}$. The GSD value of the smoke particles could be calculated from Equation (1) [30], while the mass median aerodynamic diameter (MMAD) value was defined as the aerodynamic diameter at $50 \%$ of the cumulative oversize percentage of the smoke particles.

$$
\text { GSD }=\frac{d_{84.1 \%}}{d_{50 \%}}=\frac{d_{50 \%}}{d_{15.9 \%}}
$$

\subsection{Total Smoke Particle Mass Concentration}

A vacuum air sampler (Daikawa, 2VP-120L, Tokyo, Japan) was used to collect the total particle mass concentration (TPMC) of the smoke particles from the bio-char combustion. A 110 mm-diameter quartz-type fibrous filter (ADVENTEC, QR-100, Tokyo, Japan) was placed in the filter holder. The experimental air flow rate was set at $100 \mathrm{lpm}$ by using the flow controller system (Figure 2). The TPMC value was measured and calculated under the same conditions as for the particle size distribution.

\subsection{Analysis of PAHs Extraction}

PAHs were the priority pollutants [31] and could be divided into sixteen forms, including Acenaphthene, Acenaphthylene, Anthracene, Fluorene, Phenanthrene, Indeno[1,2,3-cd]pyrene, Naphthalene, Pyrene, Chrysene, Fluoranthene, Dibenz[a,h]anthracene, Benz[a]anthracene, Benzo[a]pyrene, Benzo[b]fluoranthene, Benzo[k]fluoranthene, and Benzo[g,h,i]perylene as defined by the United States Environmental Protection Agency (USEPA). In this study, PAHs on the sampled filter were extracted by using an ultrasonic extraction technique (USE). Small pieces of the filter sample (about $5 \times 5 \mathrm{~mm}$ ) were ultrasonically extracted twice in ethanol:benzene $(1: 3, v / v)$ for 15 min each. After the addition of $50 \mu \mathrm{L}$ of dimethyl sulfoxide, the extracted solution was concentrated by using a rotary evaporator (Buchi, Switzerland) to remove the benzene and ethanol, and the filtrate was then kept in a refrigerator at $-20{ }^{\circ} \mathrm{C}$ prior to analysis.

\subsection{HPLC Analysis}

Following the procedure established in a previous report [32,33], HPLC/UV detection was used for the detection of polycyclic aromatic hydrocarbons in the environmental samples. In this study, the polycyclic aromatic hydrocarbons were extracted and analyzed by using liquid chromatography (1100, Agilent Technologies, Waldbronn, Germany) with ultraviolet absorption detection. The mixtures and extracts were injected into a UPS C18 reversed-phase column (particle size $5 \mu \mathrm{m}, 250 \mathrm{~mm}$ length, $4.6 \mathrm{~mm}$ diameter, Hibar Fertigsaube RT, Darmstadt, Germany) with a guard column. The mobile phase was a mixture of water and acetonitrile with gradient elution and a flow rate of $1.0-1.2 \mathrm{~mL} / \mathrm{min}$. The wavelength of the UV detector was $254 \mathrm{~nm}$ for each PAH. The external standard solutions were prepared from sixteen PAH mix standards [34]. Qualitative analysis of the PAHs was based on the comparison of the UV spectra and retention time values with reference standards by using the Chemstation program. 


\subsection{Toxic Potency Assessment of PAHs}

For the potential health risks of exposure to PAHs, the total BaPTE concentration contributed by the PAH components were calculated from [35]:

$$
B a P T E=\sum_{i}\left(P A H_{i} \times T E_{i}\right)
$$

where $P A H_{i}$ and $T E_{i}$ were the PAHs component measured concentration and toxicity equivalent factor of $i$-th.

\subsection{The Total BaPTE Concentration Value Expression}

The rate reaction equations, zero and first order, were used to predict the total of $B a P T E$ concentration value change in the bio-char combustion. For the zero order, the reaction rate was constant at all times. Meanwhile, the reaction rate in first order depended on the substrate concentration. Thus, the rate reaction equations could be written:

The zero-order rate reaction equation could be calculated from:

$$
\frac{d(B a P T E)}{d t}=k_{T p}
$$

The first-order rate reaction equation could be calculated from:

$$
\frac{d(B a P T E)}{d t}=k_{T p}(B a P T E)
$$

$k_{T p}$ is the temperature dependent rate constant $\left(\mathrm{h}^{-1}\right)$ and $t$ is the combustion time (h).

According to the Arrhenius equation, where $T p$ is the particle temperature (K), $E$ is the activation energy of the rate constant $\left(\mathrm{J} \mathrm{mol}^{-1}\right), R$ is the universal gas constant $\left(\mathrm{J} \mathrm{mol}^{-1} \mathrm{~K}^{-1}\right)$, and $A$ is the frequency factor $\left(\mathrm{h}^{-1}\right)$. Thus, Equation (5) could be written:

$$
k_{T p}=A \times \exp \left(\frac{-E}{R T_{p}}\right)
$$

Following a typical approach for two-color pyrometry, Wien's law [36,37], Tp was calculated by two-color pyrometry comparing the radiation intensity at 550 and $700 \mathrm{~nm}$ recorded by the photo-multipliers. Thus, Equation (6) could be written:

$$
T_{p}=\alpha \frac{\lambda_{1}-\lambda_{2}}{\lambda_{1} \lambda_{2}}\left[\ln \left(k\left(\frac{\lambda_{1}}{\lambda_{2}}\right)^{5}\right)+\ln \left(\frac{I_{2}}{I_{1}}\right)\right]^{-1}
$$

$\lambda_{1}=550 \mathrm{~nm}, \lambda_{2}=700 \mathrm{~nm}, \alpha$ is the second radiation constant, $k$ is the calibration constant, $I_{1}$ is the signal intensity of $\lambda_{1}$ and $I_{2}$ is the signal intensity of $\lambda_{2}$, respectively.

The response surface methodology, or RSM, is a collection of statistical and mathematical techniques that are useful for developing empirical model building, optimizing processes parameters, and finding the interaction of several affecting factors. For an equation to predict the $T p$ value changes during POSS bio-char combustion, the bio-char moisture content $(M R)$ and drying time $(t)$ would be the input variables. Thus, the functions were specified by Equation (7):

$$
T_{p}=F(M R, t)
$$

It is agreeable to assume the random experimental error value was zero. The prediction models $T p$ value changes could be calculated from Equation (8):

$$
T_{p}=a_{0}+a_{1} M R+a_{2} t
$$


Thus, Equation (5) changes to Equation (9):

$$
k_{T p}=A \times \exp \left(\frac{-E}{R\left(a_{0}+a_{1} M R+a_{2} t\right)}\right)
$$

\subsection{The Total BaPTE Concentration Value Prediction}

The total BaPTE concentration value change in bio-char combustion was predicted. The zero- and first-order rate reactions could be given by:

The zero-order prediction models could be calculated from Equation (10):

$$
\operatorname{BaPTE}(t)=B a P T E_{0}+k_{T p} t
$$

The first-order prediction models could be calculated from Equation (11):

$$
\operatorname{BaPTE}(t)=\mathrm{BaPTE}_{0}+\exp \left(k_{T p} t\right)
$$

\subsection{Statistical Analysis}

The experimental data were analyzed for a factorial experiment with a completely randomized design (CRD). The significant model terms were evaluated by the probability value ( $p$-value) at $95 \%$ confidence interval.

\section{Results and Discussion}

\subsection{Temperature Resulting}

For a clean air speed of $0.1 \mathrm{~m} / \mathrm{s}$ and the lowest POSS bio-char moisture content (15\% d.b.), Figure 3 presents the Tp and temperature values of the POSS bio-char combustion at varying distances above the fire base. The POSS bio-char combustion had three phases: preheating, degassing, and charcoal, the same as para rubber wood combustion [17] and others [38-40]. Figure 3 illustrates that the locations above the fire base had a prime influence on the measured temperature values. Figure 3 shows the highest temperature value of about $1145^{\circ} \mathrm{C}$ was found $300 \mathrm{~mm}$ above the fire base in the preheating phase. The temperature value decreased with the increasing the distance above the fire base, while the highest $T p$ value was about $1382{ }^{\circ} \mathrm{C}$ in the same place as the distancing temperature experiment.

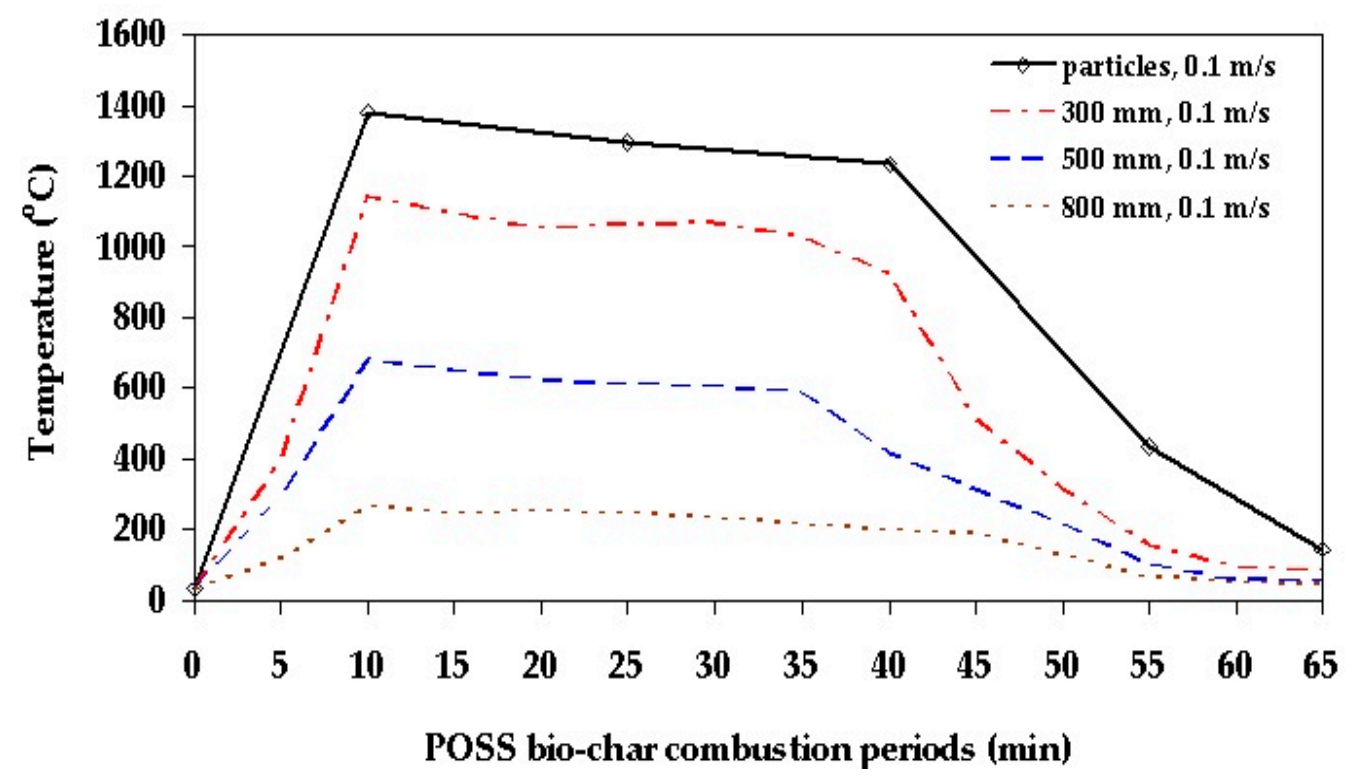

Figure 3. The temperature under the condition of $0.1 \mathrm{~m} / \mathrm{s}$ clean air speed and $15 \%$ d.b. of POSS bio-char moisture content for the particles and different distances above the fire base. 
For a clean air speed of $0.1 \mathrm{~m} / \mathrm{s}$, Figure 4 shows that the POSS bio-char moisture content had a prime influence on increasing temperature values above the fire base (the chart is not shown for $45 \%$ d.b.). The temperature value decreased with increasing POSS bio-char moisture content. This is the same result as para rubber wood combustion [17] and others [38-40]. From Figure 5, where the clean air speeds were raised to $0.2 \mathrm{~m} / \mathrm{s}$ and $0.3 \mathrm{~m} / \mathrm{s}$, respectively, the rise in clean air speed affected both the temperature values of the POSS bio-char combustion, $\mathrm{Tp}$, and the temperature at each location above the fire base. At the same POSS bio-char moisture content (the chart shown for the lowest POSS bio-char moisture content, $15 \%$ d.b.), clean air speeds increased with decreasing $T p$ and temperature value at $300 \mathrm{~mm}$ above the fire base, but at $500 \mathrm{~mm}$ and $800 \mathrm{~mm}$ above the fire base, the chart shows that the temperature increased. For this reason, the rise in clean air speed affects the point of complete combustion, temperature, and end of the burning period. This agreed with the results reported by [41-43].

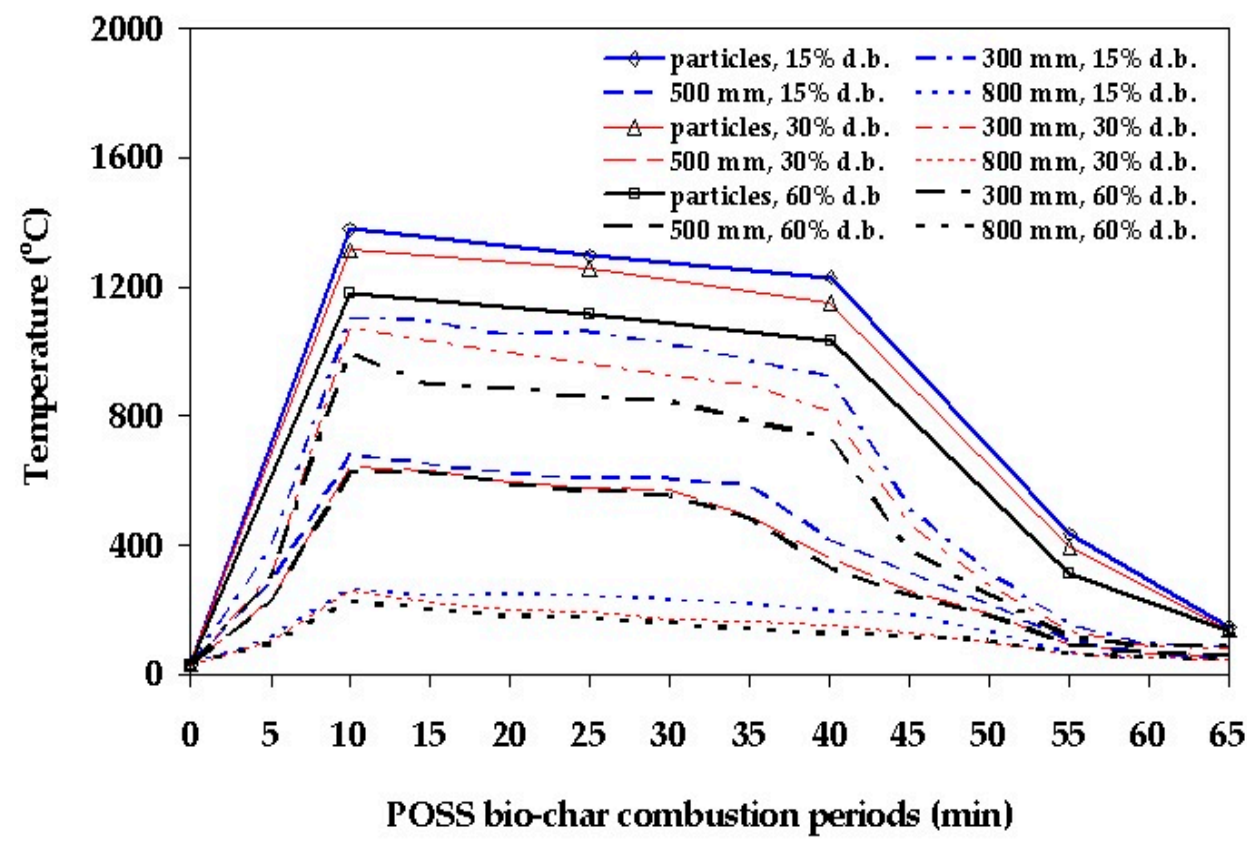

Figure 4. The temperature under condition of $0.1 \mathrm{~m} / \mathrm{s}$ clean air speed, and different distance locations above the base of the fire and moisture content.

\subsection{Smoke Particles Size Distribution (SPSD)}

The SPSD values of the POSS bio-char combustion measurement, by using an eightstate Andersen sampler, from four samples with varying moisture content of $15,30,45$, and $60 \%$ d.b are presented in Figure 6. The results showed that the size distribution indicated a single-mode behavior. The MMAD values were found to be 0.44 to 1.05 micron at various moisture contents and combustion periods. For this reason, the reduced moisture content and rise in the combustion period reduced the smoke particles' size distribution. This agreed with the results reported by $[17,20,22]$, which studied the particles' size distribution from para rubber wood combustion.

\subsection{Total Particle Mass Concentration of Smoke Particles (TPMC)}

Figure 7 presents the results of the TPMC values of smoke particles from POSS biochar combustion. At the beginning of the combustion period, TPMC values were found to be 11.25 to $37.42 \mathrm{mg} / \mathrm{m}^{3}$ and then constantly decreased until the 60th minute, when combustion was finished. This was because the degree of incomplete combustion decreased after water evaporation in all fuels, including POSS bio-char [44-47] in this experiment. 


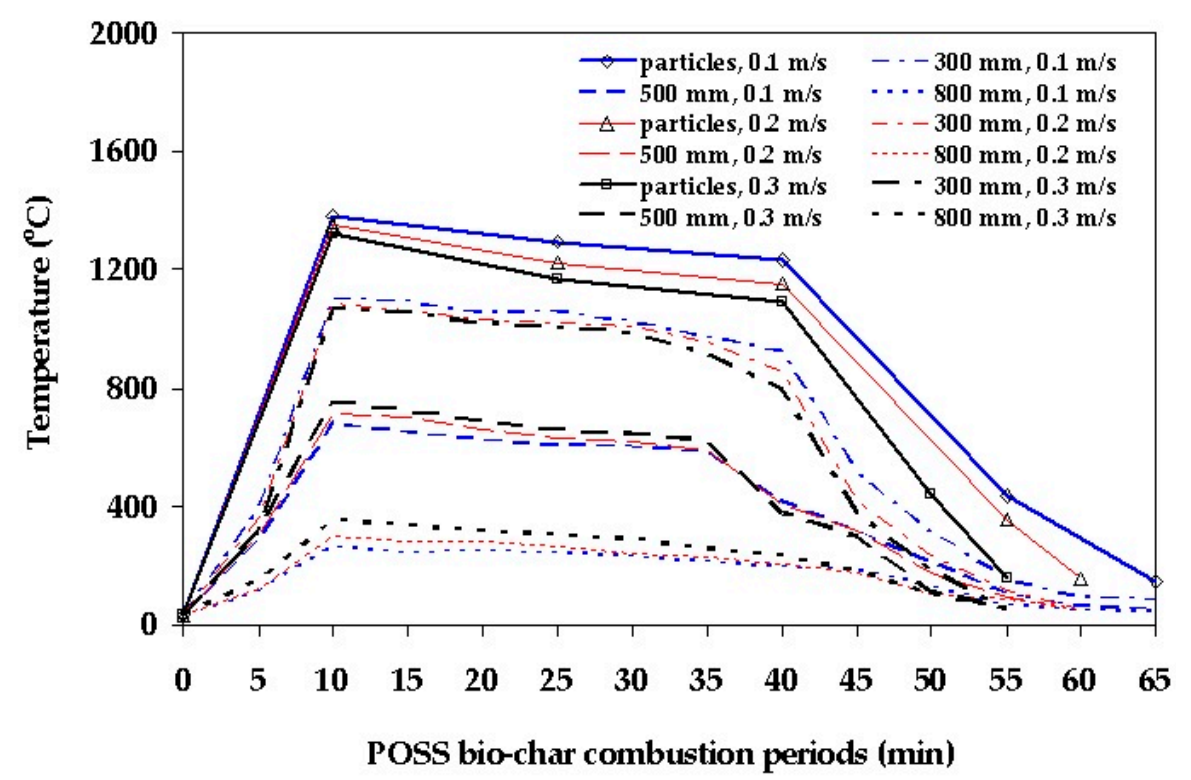

Figure 5. The temperature of $15 \%$ d.b. of POSS bio-char moisture content for different clean air speeds and distance locations above the base of the fire.

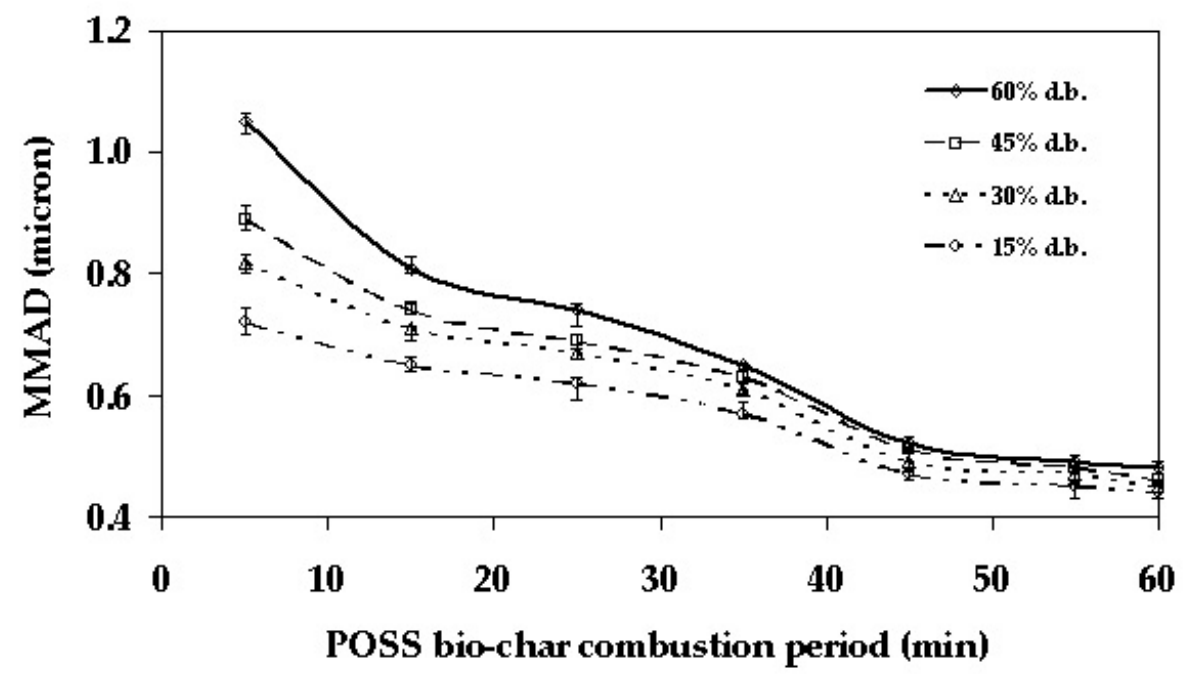

Figure 6. MMAD emission from the POSS bio-char combustion for different moisture contents.

\subsection{PAH Components}

Table 1 presents the results data for each PAH concentration component at different combustion periods with the highest POSS bio-char moisture content (60\% d.b.) and 0.1 $\mathrm{m} / \mathrm{s}$ clean air speed. In this experiment, the PAH compounds from the POSS bio-char combustion could be classified into two groups, 2-3 rings and 4-6 rings. Phenanthrene, Acenaphthene, Fluorene, Naphthalene, Acenaphthylene, and Anthracene were the 2-3 rings of PAH compounds [48,49], while the 4-6-ring PAHs were Indeno[1,2,3-cd]pyrene, Fluoranthene, Benz[a]anthracene, Chrysene, Pyrene, Benzo[b]fluoranthene, Benzo[k]fluoranthene, Benzo[a]pyrene, Dibenz[a,h]anthracene, and Benzo[g,h,i]perylene [48,49]. The influence of fuel moisture content and the combustion period on the concentration of 2-3-ring and 4-6-ring PAHs was like the influence on the total smoke particle concentration and PAH concentration. This result showed that low concentrations of PAHs after a long period of burning may result, in part, from the decomposition of the PAHs. This agreed with the results reported by $[15,28,38,39]$. Figure 8 shows the mass fraction profile of the 16 PAHs in the smoke particles generated from the POSS bio-char change during the combustion process at various clean air speeds (data not shown for $0.2 \mathrm{~m} / \mathrm{s}$ ). The total concentration of 
the 2-3-ring PAHs value was lower than the 4-6-ring PAHs value at the initial combustion period, with the highest moisture content of the POSS bio-char (60\% d.b.). However, the total concentration of the 2-3-ring PAHs value continually increased until it was higher than the 4-6-ring PAHs value during the middle and final combustion periods. The results showed that an increase in clean air speed and time period had a strong influence in decreasing the 4-6-ring PAHs values. This was probably the result of the decomposition and evaporation of the 4-6-ring PAHs. Figure 9 shows that the decrease in the POSS bio-char moisture content had a high influence on decreasing the 4-6-ring PAHs values. This was because the degree of incomplete combustion decreases after the evaporation of the water in every biomass fuel $[50,51]$, including the POSS bio-char in this experiment.

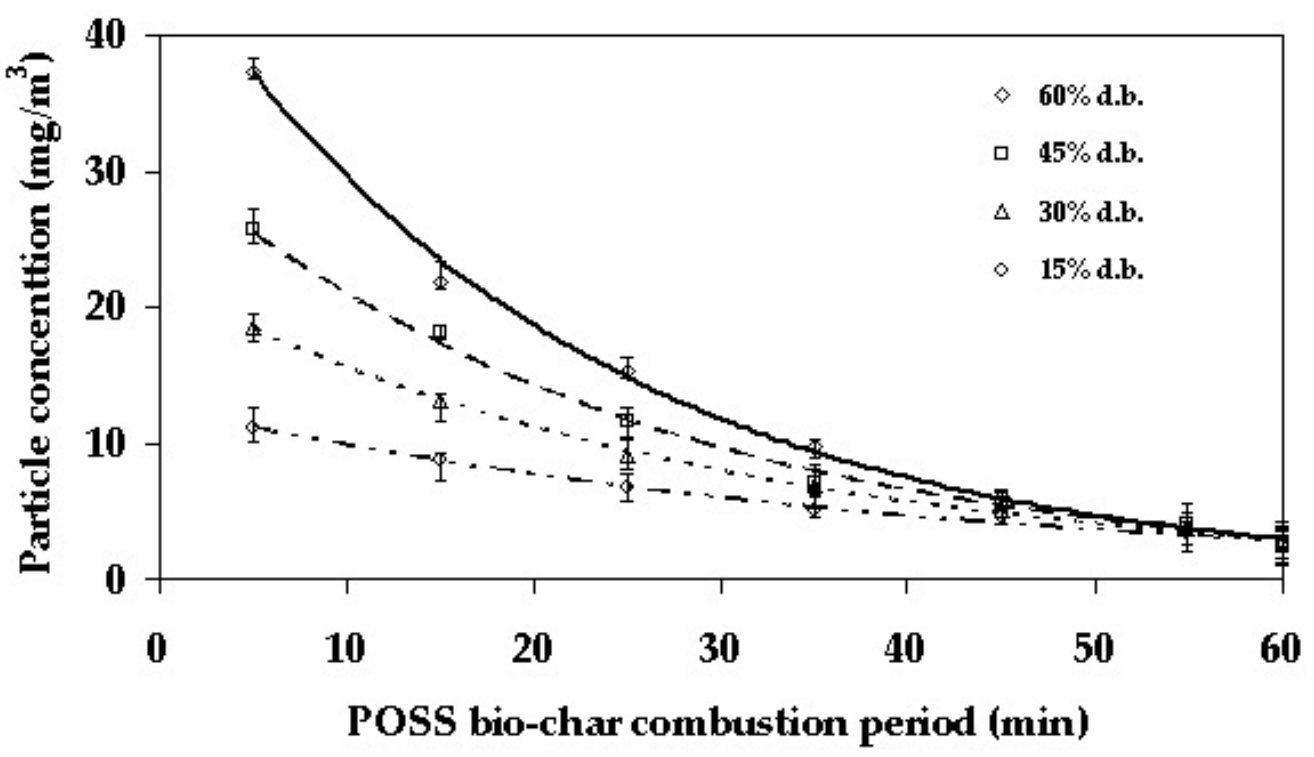

Figure 7. Total particle mass concentration emission from the POSS bio-char combustion for different moisture contents.

Table 1. The PAH concentration components for different combustion periods at the highest palm oil sewage sludge bio-char moisture content ( $60 \%$ d.b.) and $0.1 \mathrm{~m} / \mathrm{s}$ clean air speed. The unit is in $\mathrm{ng} / \mathrm{m}^{3}$.

\begin{tabular}{|c|c|c|c|c|c|c|c|}
\hline \multirow{2}{*}{$\begin{array}{c}\text { Moisture } \\
\text { Content }(\% \mathrm{db})\end{array}$} & \multirow{2}{*}{ PAHs } & \multicolumn{6}{|c|}{ Combustion Periods (min) } \\
\hline & & 5 & 15 & 25 & 35 & 45 & 55 \\
\hline \multirow{20}{*}{60} & Phenanthrene & 1789.15 & 876.38 & 177.57 & 65.34 & 11.42 & 7.56 \\
\hline & Acenaphthene & $15,523.64$ & 8276.69 & 2246.35 & 2028.89 & 1175.47 & 785.59 \\
\hline & Fluorene & $32,168.28$ & $17,028.43$ & 6578.23 & 4812.62 & 3519.94 & 1927.25 \\
\hline & Naphthalene & $13,276.43$ & 5579.85 & 2543.19 & 1875.25 & 1556.22 & 1348.28 \\
\hline & Acenaphthylene & $19,987.12$ & 9875.82 & 5129.27 & 4576.95 & 3487.77 & 1924.12 \\
\hline & Anthracene & 1253.22 & 578.26 & 431.87 & 312.25 & 246.16 & 124.82 \\
\hline & Indeno[1,2,3-cd]pyrene & 7986.39 & 3876.41 & 3125.85 & 1672.06 & 715.52 & 297.75 \\
\hline & Fluoranthene & 4127.34 & 1821.37 & 997.82 & 731.29 & 562.04 & 312.05 \\
\hline & Benz[a]anthracene & $29,871.69$ & $13,089.95$ & 7345.23 & 4137.72 & 1987.36 & 1198.27 \\
\hline & Chrysene & $19,954.26$ & 8765.29 & 6547.18 & 3116.75 & 2114.47 & 1375.57 \\
\hline & Pyrene & $21,143.27$ & 9425.21 & 5478.22 & 2348.83 & 1556.94 & 1127.85 \\
\hline & Benzo[b]fluoranthene & $27,165.25$ & $12,042.58$ & 5672.85 & 2231.85 & 1349.08 & 985.81 \\
\hline & Benzo[k]fluoranthene & $27,287.12$ & $11,875.49$ & 6221.42 & 2998.77 & 1993.81 & 1203.35 \\
\hline & Benzo[a]pyrene & $26,549.48$ & $12,079.63$ & 7134.35 & 4129.52 & 1678.54 & 425.56 \\
\hline & Dibenz[a,h]anthracene & $27,547.94$ & $12,317.42$ & 5869.82 & 3459.83 & 1876.65 & 921.32 \\
\hline & Benzo[g,h,i]perylene & $41,235.29$ & $19,365.61$ & $10,984.89$ & 4186.62 & 1731.22 & 865.29 \\
\hline & Total & $316,865.87$ & $146,874.39$ & $76,484.11$ & $42,684.54$ & $25,562.61$ & $14,830.44$ \\
\hline & $2-3$ rings & $83,997.84$ & $42,215.43$ & $17,106.48$ & $13,671.30$ & 9996.98 & 6117.62 \\
\hline & $4-6$ rings & $232,868.03$ & $104,658.96$ & $59,377.63$ & $29,013.24$ & $15,565.63$ & 8712.82 \\
\hline & BaPTE & $64,060.91$ & $28,825.47$ & $15,443.50$ & 8785.99 & 4212.56 & 1746.49 \\
\hline
\end{tabular}




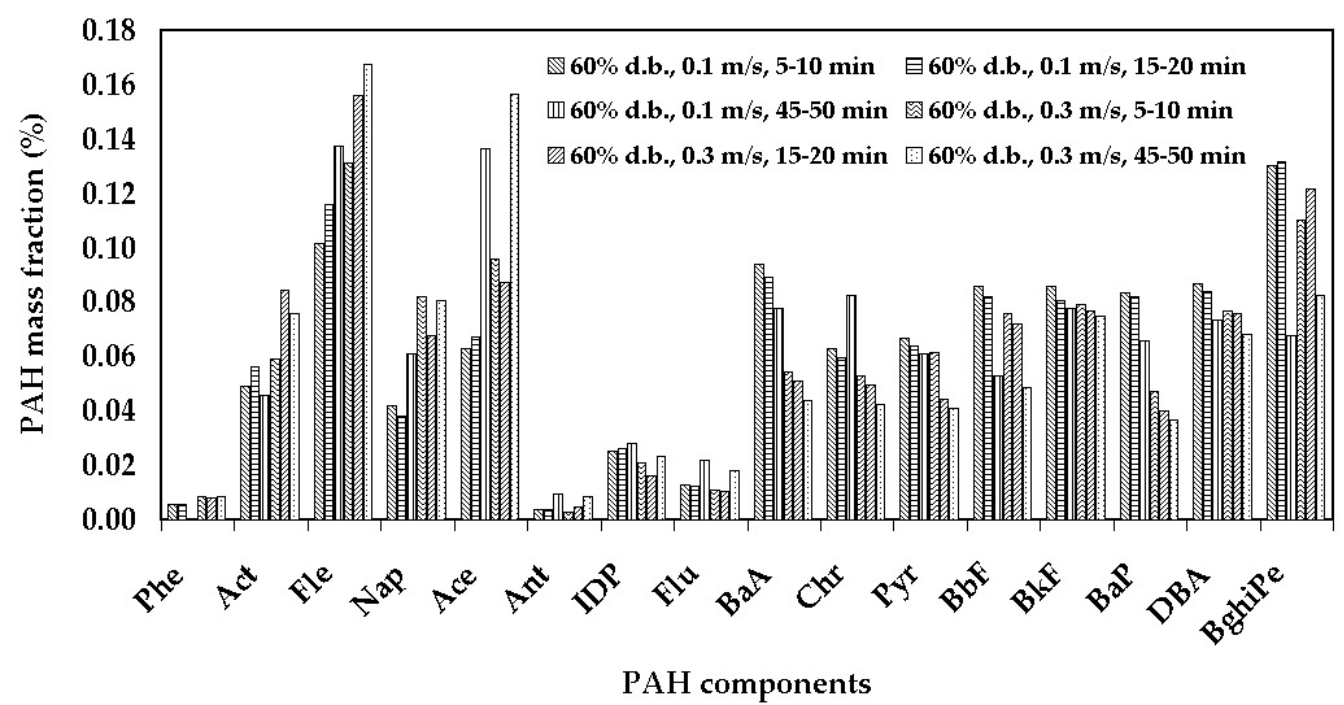

Figure 8. Mass faction of each PAH component in smoke particle samples from the palm oil sewage sludge bio-char combustion for different clean air speeds and combustion periods (Phe = Phenanthrene, Act $=$ Acenaphthylene, Fle $=$ Fluorene, $\mathrm{Nap}=$ Naphthalene, Ace $=$ Acenaphthene, Ant $=$ Anthracene, IDP $=$ Indeno[1,2,3-cd]pyrene, Flu = Fluoranthene, $\mathrm{BaA}=$ Benz[a]anthracene, $\mathrm{Chr}=$ Chrysene, Pyr $=$ Pyrene, $\mathrm{BbF}=$ Benzo[b]fluoranthene, BkF = Benzo[k]fluoranthene, $\mathrm{BaP}=$ Benzo[a]pyrene, DBA = Dibenz[a,h]anthracene, and BghiPe = Benzo[g,h,i]perylene).

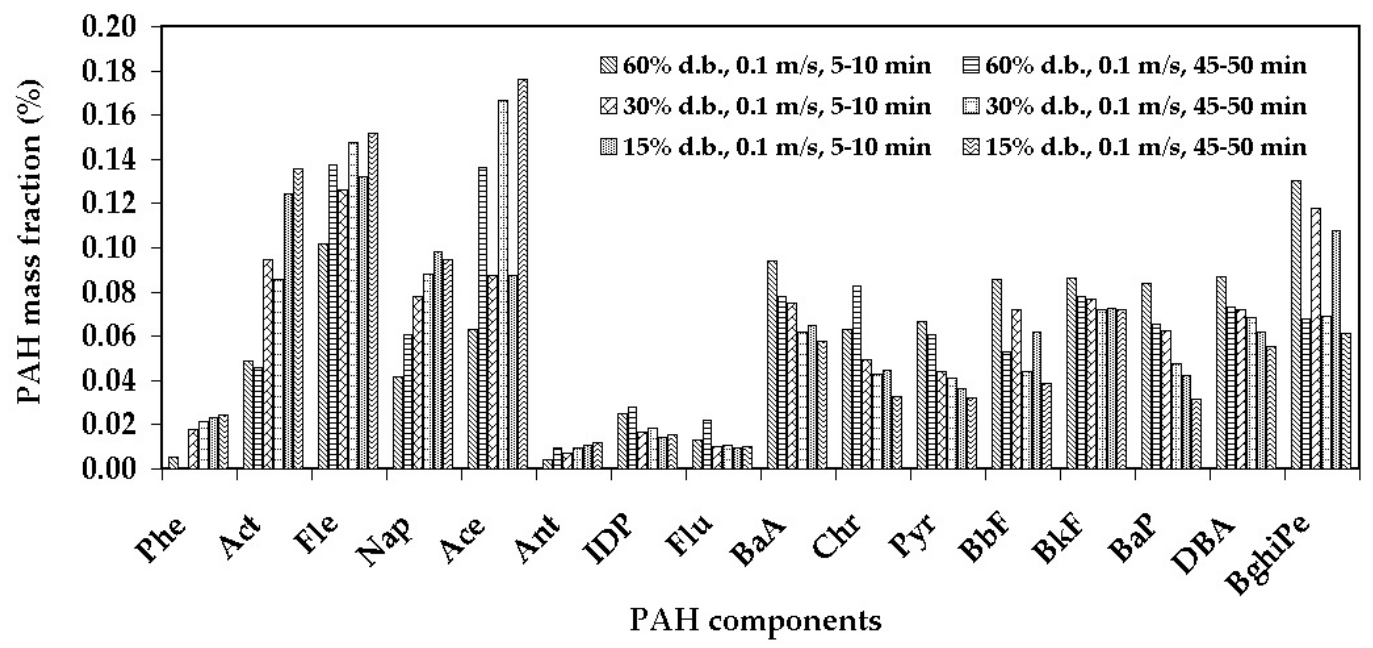

Figure 9. Mass faction of each $\mathrm{PAH}$ component in smoke particle samples from the palm oil sewage sludge bio-char combustion for different moisture contents and combustion periods (Phe $=$ Phenanthrene, Act $=$ Acenaphthylene, Fle $=$ Fluorene, Nap $=$ Naphthalene, Ace = Acenaphthene Ant $=$ Anthracene, IDP = Indeno[1,2,3-cd]pyrene, Flu = Fluoranthene, BaA = Benz[a]anthracene, $\mathrm{Chr}=$ Chrysene, $\mathrm{Pyr}=$ Pyrene, $\mathrm{BbF}=$ Benzo[b]fluoranthene, $\mathrm{BkF}=$ Benzo[k]fluoranthene, $\mathrm{BaP}=$ Benzo[a]pyrene, DBA = Dibenz[a,h]anthracene, and BghiPe = Benzo[g,h,i]perylene).

\subsection{The Total BaPTE Concentration Alue}

Figure 10 presents the results of total BaPTE concentration of the smoke particles from POSS bio-char combustion. In the initial combustion period, the BaPTE value was found to be $23,145.64$ to $64,060.91 \mathrm{ng} / \mathrm{m}^{3}$; then, it continually decreased until the 60 th minute. The BaPTE value was found to be 435.62 to $1746.49 \mathrm{ng} / \mathrm{m}^{3}$. This result showed that the increase in time period and the POSS bio-char moisture content had a prime influence on decreasing the total PAHs and BaPTE values, synonymous with the TPMC and MMAD values. 


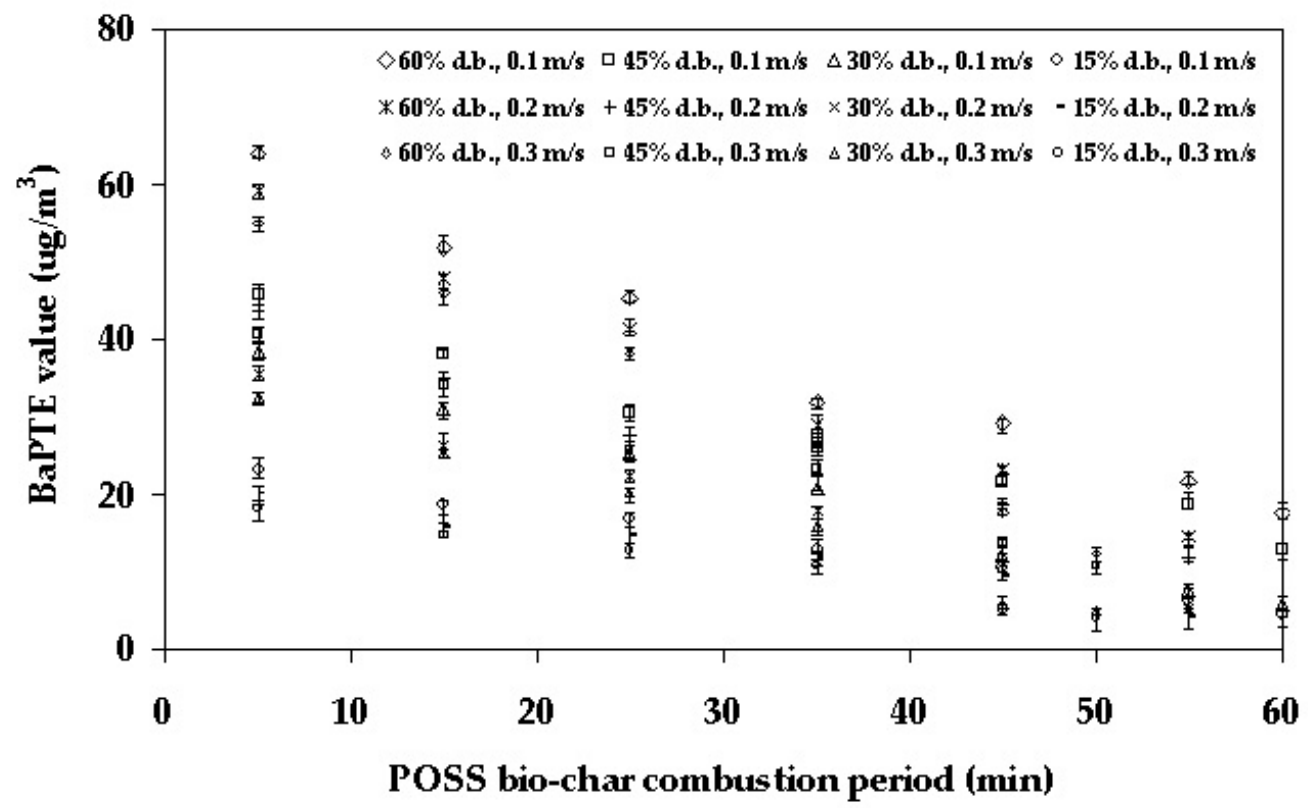

Figure 10. BaPTE value in the smoke particle samples from the POSS bio-char combustion for different the clean air speeds and moisture contents.

The relationship between the Tp value changed during the POSS bio-char combustion and with the bio-char moisture content. When substituting the $\mathrm{a}_{0}, \mathrm{a}_{1}$ and $\mathrm{a}_{2}$ coefficient values which were calculated by using the least-squares method in Equation (8), the equation of the Tp value changed and could be written as shown in Equation (12). The experimental and predictable total BaPTE values of the POSS bio-char samples throughout the combustion period are presented in Table 2. The results showed that the total BaPTE value of the POSS bio-char burning was between 65.7 and 261.6. The increase in moisture content of the POSS bio-char samples had a high influence on increasing the total BaPTE values. Meanwhile, when increasing the clean air speed, the total BaPTE values decreased.

$$
T_{p}=69.5083-1.1872 M R+0.0056 t
$$

Table 2. The experimental and predictable total BaPTE values of the palm oil sewage sludge bio-char samples throughout the combustion time.

\begin{tabular}{|c|c|c|c|c|c|}
\hline \multirow{2}{*}{$\begin{array}{c}\text { Velocity } \\
(\mathrm{m} / \mathrm{s})\end{array}$} & \multirow[t]{2}{*}{$M R$ (\%d.b.) } & \multirow{2}{*}{$\begin{array}{l}\text { Combustion } \\
\text { Time (min) }\end{array}$} & \multirow{2}{*}{$\begin{array}{c}\sum B a P T E \text { Value } \\
\text { Experiment } \\
\left(\mu \mathrm{g} / \mathrm{m}^{3}\right)\end{array}$} & \multicolumn{2}{|c|}{$\begin{array}{c}\sum B a P T E \text { Value Predictior } \\
\left(\mu \mathrm{g} / \mathrm{m}^{3}\right)(\text { Order})\end{array}$} \\
\hline & & & & Zero & First \\
\hline \multirow[t]{4}{*}{0.1} & 15 & 60 & $93.1 \pm 0.6^{\mathrm{de}}$ & $96 . .4$ & 95.6 \\
\hline & 30 & 60 & $141.3 \pm 0.8^{d}$ & 152.8 & 155.7 \\
\hline & 45 & 60 & $194.9 \pm 1.2^{h}$ & 192.3 & 194.1 \\
\hline & 60 & 60 & $261.6 \pm 1.5^{\mathrm{ab}}$ & 255.1 & 264.6 \\
\hline \multirow[t]{4}{*}{0.2} & 15 & 55 & $76.2 \pm 0.3^{c}$ & 75.2 & 77.9 \\
\hline & 30 & 55 & $118.1 \pm 0.6^{\mathrm{de}}$ & 123.5 & 121.7 \\
\hline & 45 & 55 & $163.1 \pm 0.8^{\mathrm{d}}$ & 161.2 & 167.9 \\
\hline & 60 & 55 & $214.9 \pm 1.2^{h}$ & 211.3 & 215.1 \\
\hline \multirow[t]{4}{*}{0.3} & 15 & 50 & $65.7 \pm 0.3^{c}$ & 63.6 & 67.5 \\
\hline & 30 & 50 & $104.5 \pm 0.9^{\mathrm{a}}$ & 101.2 & 105.7 \\
\hline & 45 & 50 & $148.1 \pm 0.7^{\mathrm{ef}}$ & 152.8 & 156.3 \\
\hline & 60 & 50 & $195.4 \pm 1.0 \mathrm{fg}$ & 197.1 & 199.1 \\
\hline
\end{tabular}

$\mathrm{a}-\mathrm{h}$ Different letters in the same column indicate a significant difference at $p$-value $(p<0.05)$. 


\subsection{The Rate of Constant Determination}

Table 3 presents the activation energy and frequency factor values of the expressed rate constant at various clean air speed values and orders. In both orders, these values were determined by the total BaPTE values from the experiments and a plot to find and compare the constant of experimental reaction rate.

Table 3. The activation energy and frequency factor values of the expressed rate constant.

\begin{tabular}{ccccc}
\hline \multirow{2}{*}{ Velocity (m/s) } & \multicolumn{4}{c}{ Order of the Reaction Rate Constant } \\
\cline { 2 - 5 } & Zero & \multicolumn{3}{c}{ First } \\
\cline { 2 - 5 } & $48.8 \times 10^{8}$ & $96,597.4$ & $47.1 \times 10^{8}$ & E ( J/mol) \\
\hline 0.1 & $29.2 \times 10^{8}$ & $91,982.9$ & $25.6 \times 10^{8}$ & $85,216.8$ \\
0.2 & $15.4 \times 10^{8}$ & $88,376.8$ & $11.2 \times 10^{8}$ & $83,287.9$ \\
0.3 & &
\end{tabular}

In this model, as a procedure to determine the best fit line to data, the least-squares technique was used to calculate the activation energy and frequency factor values of the expressed rate constant at various clean air speeds values and orders. Table 3 shows that apart from the moisture content, the clean air speed value was another factor that affected the reaction rate constant. Increasing the clean air speed decreased both the activation energy and the frequency factor values for the same order of reactions.

\subsection{The Total BaPTE Value Prediction}

Comparing the total BaPTE value data between the experimental results and the prediction values, the first-degree model had a better fit in predicting than the zero-degree model; this result was confirmed by the higher mean of the coefficient of determination (Figure 11a,b), respectively. The mean of the coefficient of determination, or $\mathrm{R}^{2}$, was between 0.9728 and 0.9875 , which is satisfactory (Figure 11b). Hence, the response of both models presented an increasing trend of the total BaPTE values as the POSS bio-char combustion period progressed.

For the cost side in the production process, the POSS bio-char produced by this technique had a greater cost than the normal technique by about $1.5 \%$. It was referred by the Department of Alternative Energy Development and Efficiency, Ministry of Energy [52]. 


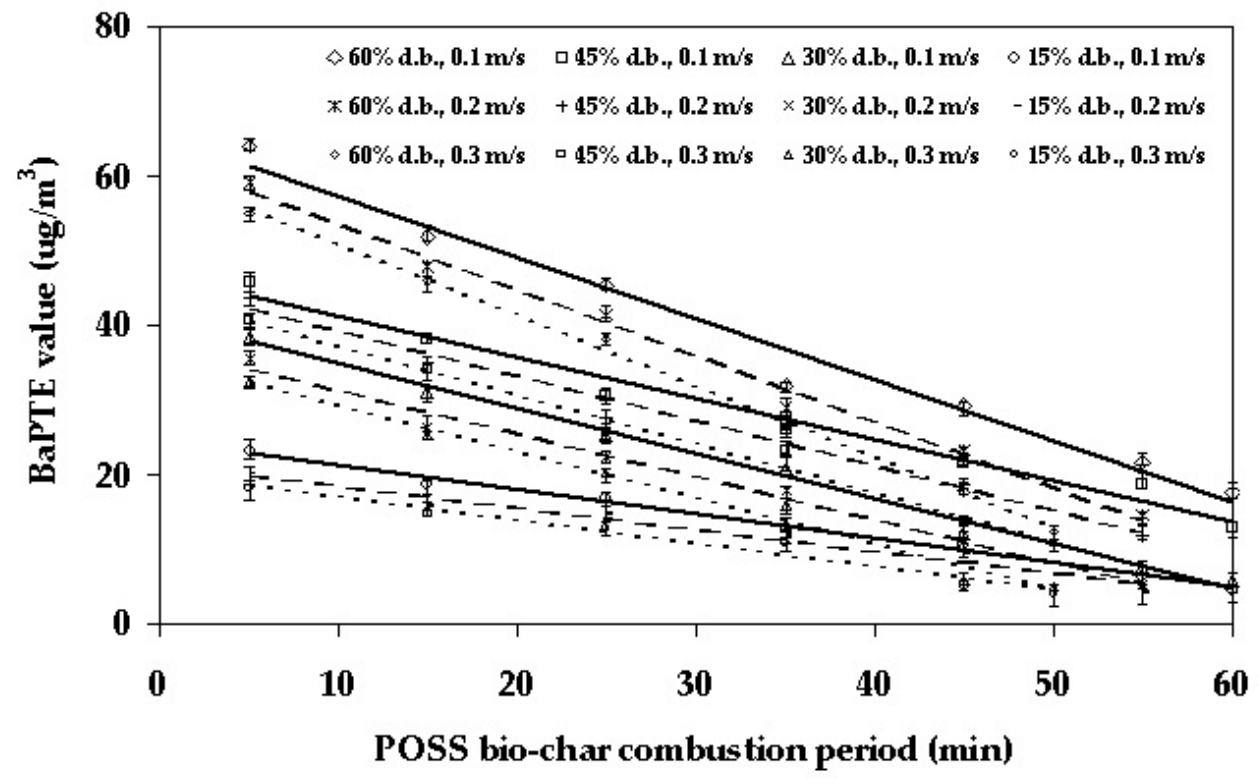

(a)

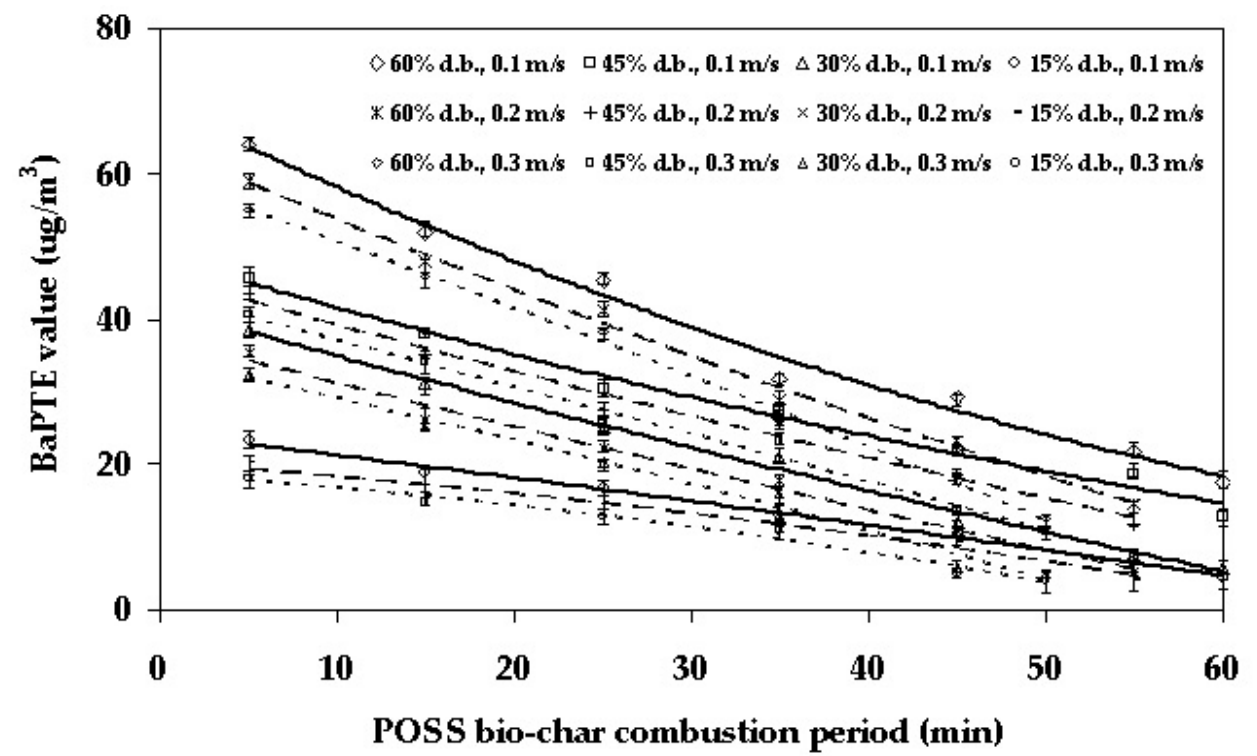

(b)

Figure 11. Comparison of predicted and experimental BaPTE values: (a) zero-degree model; (b) first-degree model.

\section{Conclusions}

The results conclude the MMAD values of the POSS bio-char combustion were found to be 0.44 to 1.05 micron at various moisture contents and burning periods. The POSS biochar moisture content, clean air speed value and burning period changed the temperature above the base of the fire. The MMAD, TPMC, and PAHs values decreased when decreasing the moisture content and increasing the POSS bio-char combustion period. The results showed that an increase in moisture content of the POSS bio-char sample had a prime influence on increasing the total BaPTE values. While the clean air speed values increased, the total BaPTE values decreased. The first-degree model had a better fit for the total BaPTE values prediction than the zero-degree model. Future work on this knowledge has been improved. The size values and principal compositions of POSS bio-char, pressure, oxygen concentrations in atmospheres and atmosphere-relative humidity have been considered and analyzed. 
Author Contributions: Conceptualization, W.K. and P.D.; writing-original draft preparation, W.K.; resources, W.K.; writing-review and editing, P.D. All authors have read and agreed to the published version of the manuscript.

Funding: This research received no external funding.

Institutional Review Board Statement: Not applicable.

Informed Consent Statement: Not applicable.

Data Availability Statement: Not applicable.

Acknowledgments: The authors thank the Center of Excellence in Technology, Agri, Food, Renewable Energy and Energy Efficiency Enhancement for the sustainable community and industrial development and King Mongkut's Institute of Technology Ladkrabang (KMITL), Prince of Chumphon Campus for providing the opportunity to perform this research.

Conflicts of Interest: The authors declare no conflict of interest.

\section{References}

1. Zahri, I.; Wildayana, E.; Thony, A.; Adriani, D.; Harun, H. Impact of conversion from rice farms to oil palm plantations on socio-economic aspects of ex-migrants in Indonesia. Agric. Econ.-Czech. 2019, 65, 579-586. [CrossRef]

2. Office of Industrial Economics. 2020. Available online: http:/ / www.oie.go.th (accessed on 19 June 2021).

3. Agricultural Commodities Price Report of Thailand. 2020. Available online: https://www.bot.or.th (accessed on 27 January 2021).

4. Office of Agricultural Economics. Ministry of Agriculture and Cooperatives. 2019. Available online: http:///www.devex.com (accessed on 7 July 2021).

5. Nupueng, S.; Oostrveer, P.; Mol, A. Implementing a palm oil-based biodiesel policy: The case of Thailand. Energy Sci. Eng. 2018, 6, 643-657. [CrossRef]

6. Thalassinos, I.; Politis, D. The evaluation of the USD currency and the oil prices: A VAR Analysis. Eur. Res. Stu. J. 2012, 15, 137-146.

7. Thalassinos, I.; Ugurlu, E.; Muratoglu, Y. Income Inequality and Inflation in the EU. Eur. Res. Stu. J. 2012, 15, 127-140. [CrossRef]

8. Seephueak, W.; Ngampongsai, W.; Chanjula, P. Effects of palm oil sludge in concentrate on nutrient utilization and rumen ecology of Thai native cattle fed with hay. Songklanakarin J. Sci. Technol. 2011, 33, 271-280.

9. Chavalparit, O.; Rulkens, W.; Mol, A.; Khaodhair, S. Options for environmental sustainability of the crude palm oil industry in Thailand through enhancement of industrial ecosystems. Environ. Develop. Sustain. 2006, 8, 271-287. [CrossRef]

10. Begum, S.; Kumaran, P.; Jayakumar, M. Use of oil palm waste as a renewable energy source and its impact on reduction of air pollution in context of Malaysia. In Proceedings of the 4th International Conference on Energy and Environment, Putrajaya, Malaysia, 5-6 March 2013.

11. Paepatung, N.; Nopharatana, A.; Songkasiri, W. Bio-methane potential of biological solid materials and agricultural wastes. Asian J. Energy Environ. 2009, 10, 19-27.

12. Photong, N.; Wongthanate, J. Biofuel production from bio-waste by biological and physical conversion processes. Waste Manag. Res. 2020, 338, 69-77. [CrossRef]

13. Salaudeen, I.; Sonibare, O.; Sojinu, S.; Ekundayo, O. Polycyclic aromatic hydrocarbons in air from industrial areas in Lagos and Ogun states, Nigeria. Pollution 2017, 3, 561-573.

14. Shen, G.; Preston, W.; Ebersviller, S.; Williams, C.; Faircloth, J.; Jetter, J.; Hay, M. Polycyclic aromatic hydrocarbons in fine particulate matter emitted from burning kerosene, liquid petroleum gas, and wood fuels in household cook-stoves. Energy Fuels 2017, 31, 3081-3090. [CrossRef]

15. Kalasee, W.; Teekapakvisit, C. A review of air pollution and solutions way management related to Ribbed smoked sheets (RSS) production of community-level rubber cooperatives in Thailand: Smoke, soot and PAHs particles. Pollution 2020, 6, $267-284$.

16. Pham, C.; Boongla, Y.; Nghiem, T.; Le, H.; Tang, N.; Toriba, A.; Hayakawa, K. Emission characteristics of polycyclic aromatic hydrocarbons and nitro-polycyclic aromatic hydrocarbons from open burning of rice straw in the north of Vietnam. Int. J. Environ. Res. Public Health 2019, 16, 2343. [CrossRef]

17. Kalasee, W.; Dangwilailux, P. Prediction of size distribution and mass concentration of smoke particles on moisture content and combustion period from para rubber wood burning. Appl. Sci. 2021, 11, 5649. [CrossRef]

18. Choosong, T.; Furuuchi, M.; Tekasakul, P.; Tekasakul, S.; Chomanee, J.; Jinno, T.; Hata, M.; Otani, Y. Working environment in a rubber sheet smoking factory polluted by smoke from biomass fuel burning and health influences to worker. J. Ecotechnol. Res. 2007, 13, 91-96.

19. Kalasee, W. Improvement soot particles separation equipments for rubber smoking chamber. Aerosol Air Qual Res. 2009, 9, 333-341. [CrossRef]

20. Furuuchi, M.; Tekasakul, P.; Murase, T.; Otani, Y.; Tekasakul, S.; Bai, Y. Characteristics of particulates emitted from rubber-wood burning. J. Ecotechnol. Res. 2006, 12, 135-139. 
21. Riyaphan, J.; Phumichai, T.; Neimsuwan, T.; Witayakran, S.; Sungsing, K.; Kaveeta, R.; Phumichai, C. Variability in chemical and mechanical properties of para rubber (Hevea brasiliensis) trees. Sci. Asia 2015, 41, 251-258. [CrossRef]

22. Hata, M.; Chomanee, J.; Thongyen, T.; Bao, L.; Tekasakul, S.; Tekasakul, P.; Otani, Y.; Furuuchi, M. Characteristics of nanoparticles emitted from burning of biomass fuels. J. Environ. Sci. 2014, 26, 1913-1920. [CrossRef]

23. Zhao, X.; Kim, S.-K.; Zhu, W.; Kannan, N.; Li, D. Long-range atmospheric transport and the distribution of polycyclic aromatic hydrocarbons in Changbai Mountain. Chemosphere 2015, 119, 289-294. [CrossRef]

24. Duan, F.; Liu, X.; Yu, T.; Cachier, H. Identification and estimate of biomass burning contribution to the urban aerosol organic carbon concentrations in Beijing. Atmos. Environ. 2004, 38, 1275-1282. [CrossRef]

25. Gadi, R.; Singh, D.P.; Saud, T.; Mandal, T.K.; Saxena, M. Emission estimates of particulate PAHs from biomass fuels used in Delhi, India. Human Ecol. Risk Assess. 2012, 18, 871-887. [CrossRef]

26. Singh, D.; Gadi, R.; Mandal, T.; Saud, T.; Saxena, M.; Sharma, S. Emissions estimates of PAH from biomass fuels used in rural sector of Indo-Gangetic Plains of India. Atmos. Environ. 2013, 68, 120-126. [CrossRef]

27. Bolling, A.; Pagels, J.; Yttri, K.; Barregard, L.; Sallsten, G.; Schwarze, P.; Boman, C. Health effects of residential wood smoke particles: The importance of combustion conditions and physicochemical particle properties. Part. Fibre Toxic. 2009, 6, 1-6.

28. Meincken, M.; Funk, S. Burning Characteristics of low-cost safety charcoal briquettes made from wood residues and soil for domestic use. Agroforest Syst. 2015, 89, 357-363. [CrossRef]

29. Rattanamechaiskul, C.; Junka, N.; Potichalung, J.; Wingwon, T.; Boontum, W.; Srisang, N. Whiteness index prediction of para rubber sheet during hot air drying. KKU Eng. J. 2016, 43, 331-333.

30. Hinds, W.C. Aerosol Technology, 2nd ed.; John Wiley \& Sons: New York, NY, USA, 1999.

31. Bharti, V.; Gupta, B.; Kaur, J. Novel bacterial strains Pseudomonas sp. and Bacillus sp. isolated from petroleum oil contaminated soils for degradation of flourene and phenanthrene. Pollution 2019, 5, 657-669.

32. Chomanee, J.; Tekasakul, S.; Tekasakul, P.; Furuuchi, M.; Otani, Y. Effects of moisture content and burning period on concentration of smoke particles and particle-bound polycyclic aromatic hydrocarbons from rubber-wood combustion. Aerosol Air Qual. Res. 2009, 9, 404-411. [CrossRef]

33. Song, M.; Lee, K.; Oh, S.-H.K.; Bae, M.-S. Impact of polycyclic aromatic hydrocarbons (PAHs) from an asphalt mix plant in a suburban residential area. Appl. Sci. 2020, 10, 4632. [CrossRef]

34. Song, M.; Park, C.; Choi, W.; Park, M.; Lee, K.; Park, K.; Park, S.; Bae, M.-S. Organic molecular marker from regional biomass burning-direct application to source apportionment model. Appl. Sci. 2020, 10, 4449. [CrossRef]

35. Jamhari, A.A.; Sahani, M.; Latif, M.T.; Chan, K.M.; Tan, H.S.; Khan, F.; Tahir, N.M. Concentration and source identification of polycyclic aromatic hydrocarbons (PAHs) in PM10 of urban, industrial and semi-urban areas in Malaysia. Atmos. Environ. 2014, 86, 16-27. [CrossRef]

36. Graeser, P.; Schiemann, M. Emissivity of burning bituminous coal char particles—Burnout effects. Fuel 2017, 196, 336-343. [CrossRef]

37. Graeser, P.; Schiemann, M. Investigations on the emissivity of burning coal char particles: Influence of particle temperature and composition of reaction atmosphere. Fuel 2020, 263, 116714. [CrossRef]

38. Smit, H.C.; Meincken, M. Time/temperature combustion profiles of various wood-baseed biofuels. Biomass Bioenerg. 2012, 39, 317-323. [CrossRef]

39. Schiemann, M.; Gronarz, T.; Graeser, P.; Gorewoda, J.; Kneer, R.; Scherer, V. A correlation between char emissivity and temperature. Fuel 2019, 256, 115889. [CrossRef]

40. Hagen, B.C. Onset of Smoldering and Transition to Flaming. Ph.D. Thesis, University of Bergen, Bergen, Norway, 2013.

41. Azadi, P.; Malina, R.; Barrett, S.R.H.; Kraft, M. The evolution of the biofuel science. Renew. Sustain. Energy Rev. 2017, 76, 1479-1484. [CrossRef]

42. Rogaume, T.; Auzanneau, M.; Jabouille, F.; Goudeau, J.; Torero, J. The effects of different airflows on the formation of pollutants during waste incineration. Fuel 2002, 81, 2277-2288. [CrossRef]

43. Gomez, M.; Porteiro, J.; Patiño, D.; Míguez, J. Fast-solving thermally thick model of biomass particles embedded in a CFD code for the simulation of fixed-bed burners. Energy Convers. Manag. 2015, 105, 30-44. [CrossRef]

44. Kocbach, A.; Johansen, B.V.; Schwarze, P.E.; Namork, E. Analytical electron microscopy of combustion particles: A comparison of vehicle exhaust and residential wood smoke. Sci. Total Environ. 2005, 346, 231-243. [CrossRef]

45. Mopoung, S.; Udeye, V. Characterization and evaluation of charcoal briquettes using banana peel and banana bunch waste for household heating. Am. J. Eng. Appl. Sci. 2017, 10, 353-365. [CrossRef]

46. Wiinikka, H.; Gebart, R.; Boman, C.; Bostrom, D.; Ohman, M. Influence of fuel ash composition on high temperature aerosol formation in fixed bed combustion of woody biomass pellets. Fuel 2007, 86, 181-193. [CrossRef]

47. Tissari, J.; Hytonen, K.; Lyyränen, J.; Jokiniemi, J. A novel field measurement method for determining fine particle and gas emissions from residential wood combustion. Atm Environ. 2007, 41, 8330-8344.

48. Jiao, H.H.; Rui, X.P.; Wu, S.H.; Bai, Z.H.; Zhuang, X.L.; Huang, Z.B. Polycyclic aromatic hydrocarbons in the Dagang Oilfield (China): Distribution, sources, and risk assessment. Int. J. Environ. Res. Public Health 2015, 12, 5775-5791. [CrossRef]

49. Sun, F.; Wen, D.; Kuang, Y.; Li, J.; Li, J.; Zuo, W. Concentrations of heavy metals and polycyclic aromatic hydrocarbons in needles of Masson pine (Pinus massoniana L.) growing nearby different industrial sources. J. Environ. Sci. 2010, 22, 1006-1013. [CrossRef] 
50. Barmina, I.; Lickrastina, A.; Valdmanis, R.; Zake, M.; Arshanitsa, A.; Solodovnik, V.; Telysheva, G. Effects of Biomass Composition Variations on Gasification and Combustion Characteristics. Eng. Rural Dev. 2013, 5, 382-387.

51. Liu, J.; Liu, Q.; Yang, H. Assessing water scarcity by simultaneously considering environmental flow requirements, water quantity, and water quality. Ecol. Indic. 2016, 60, 434-441. [CrossRef]

52. Department of Alternative Energy Development and Efficiency. Ministry of Energy. 2018. Available online: http:///www.dede. go.th (accessed on 12 July 2019). 